\title{
Inter-reef vertebrate communities of the Great Barrier Reef Marine Park determined by baited remote underwater video stations
}

\author{
Mike Cappo ${ }^{1,2, *}$, Glenn De'ath ${ }^{1}$, Peter Speare ${ }^{1}$ \\ ${ }^{1}$ Australian Institute of Marine Science, PMB 3, Townsville MC, Queensland 4810, Australia \\ ${ }^{2}$ School of Marine and Tropical Biology, James Cook University, Townsville, Queensland 4811, Australia
}

\begin{abstract}
A fleet of baited remote underwater video stations was set in lagoonal and inter-reef waters of the Great Barrier Reef Marine Park, across $14^{\circ}$ of latitude and the entire shelf. Counts of the maximum number seen in any one field of view were used to estimate relative abundance of 347 species of bony fishes, cartilaginous fishes and sea snakes. Boosted regression trees were used to assess the influence of depth and location of sampling sites on species richness. Multivariate regression trees and indices of specificity and fidelity (Dufrêne-Legendre indices) were used to distinguish 17 spatially contiguous vertebrate groups within a hierarchy of spatial scales. Location across the shelf and depth had the greatest influence on species richness, with peaks occurring around the $\sim 35 \mathrm{~m}$ isobath in the inter-reef waters of the reef matrix, coinciding with shallow banks and shoals. Richness increased slightly toward the equator. Nine terminal vertebrate communities parallel to the coast were distinguished inshore and offshore in deep and shallow water along a latitudinal gradient. There were important community boundaries at Bowen in the south, Townsville in the centre, and Cape Flattery in the north. Latitudinal groupings were most evident inshore. Offshore communities were spatially extensive and separated lagoonal, mid-shelf and outer-shelf sites. Community boundaries were correlated with knowledge of strong gradients in sedimentary and oceanographic processes influenced by the shape of the reef matrix and regional tides and currents.
\end{abstract}

KEY WORDS: Underwater baited video - Inter-reef $\cdot$ Demersal fish communities $\cdot$ Multivariate regression trees

Resale or republication not permitted without written consent of the publisher

\section{INTRODUCTION}

In the tropics, the biodiversity of shallow-water coral reefs has been the focus of concern and research, yet much of the world's coral is found on shelf areas in benthic communities that are non-emergent and often 10s of metres below the surface (McManus 1997, Spalding \& Grenfell 1997). These 'live bottom' communities occur on coarse sediments, palaeo-reef edges, or other outcrops and include sponges, gorgonians, alcyonarians, corals and marine plants in a wide variety of sizes and densities (Birtles \& Arnold 1988, McManus 1997, Carruthers et al. 2002). Such habitats are undoubtedly a major, but poorly known, reservoir of marine biodiversity, and their structural complexity provides habitat for a variety of other species. In some regions they have been fished intensively enough to produce changes in compositions of fish (Sainsbury et al. 1997, Laurans et al. 2004) and megazoobenthos communities (Pitcher et al. 2000).

The deeper habitats are inaccessible to the SCUBAbased survey techniques developed for shallow-water reefs, and baited 'video-fishing' techniques have recently been used alone or in association with other methods to count fishes (Ellis \& DeMartini 1995, Willis et al. 2000). Such non-extractive video techniques offer the sampling advantages of underwater visual surveys and extractive fishing techniques, whilst avoiding some of the selectivity associated with these methods (see Willis et al. 2000, Cappo et al. 2003 for reviews). 
A comparison of baited remote underwater video stations (BRUVS) and prawn (shrimp) trawls showed that the 2 techniques recorded significantly different components of the fish fauna in the Great Barrier Reef Marine Park (GBRMP) lagoon, yet both discriminated amongst the same site groups (Cappo et al. 2004). Trawls caught mainly small ( $\leq 300 \mathrm{~mm})$, sedentary, or cryptic, demersal species. The BRUVS recorded larger, mobile species from a much wider size range of families, and BRUVS were subsequently included in the suite of sampling devices used in the most comprehensive exploration of seafloor biodiversity yet undertaken in the GBRMP (Pitcher et al. 2002).

In the present paper we examine the relative influence of water depth and position across and along the GBRMP shelf on vertebrate species richness and community structure, as a prelude to a more intensive analysis of other biotic and abiotic explanatory variables. We use boosted and multivariate regression trees (De'ath 2002, 2007) and species accumulation curves to describe patterns in the richness, occurrence and abundance of fishes, sharks, rays and sea snakes sighted in standardised BRUVS surveys. The trees were used to define spatially contiguous vertebrate communities constrained by the spatial values that locate them in the GBRMP.

\section{MATERIALS AND METHODS}

Study area and sampling design. The GBRMP is the largest coral reef ecosystem on earth, with an interreef area of $210000 \mathrm{~km}^{2}$, extending over $2000 \mathrm{~km}$ of coastline and $15^{\circ}$ of latitude in an approximately northwest-southeast direction (Fig. 1). The lip of the GBR shelf occurs at only $80 \mathrm{~m}$ depth, and the shelf plain has a very flat seaward gradient $<1: 1000$ (Larcombe \& Carter 2004). Biologically informed stratification of major physical variables was used to sample as many different habitat types as possible in the 'environment space' of the GBRMP (see Pitcher et al. 2002). Between September 2003 and December 2005, a fleet of BRUVS was deployed during daylight hours about 350 to $400 \mathrm{~m}$ apart, with the prevailing wind to bracket the coordinate of each sampling site. Each replicate was considered to be independent of the others at this distance of separation (Cappo et al. 2004). At each site, a stereo-video BRUVS was deployed first, followed by 3 (97\% of sites) or occasionally 4 BRUVS with single cameras. Loss of some replicates was made up to a minimum number of 3 for the 366 sites by inclusion of footage from the stereo-video (Fig. 1).

The BRUVS consisted of a galvanized, trestle-shaped frame, enclosing a simple camera housing made from PVC pipe with acrylic front and rear ports (Fig. 2).
Sony Mini-DV HandiCams (Models TRV18E, TRV19E) with wide-angle lens adapters $(0.6 \times)$ were used in the housings. Exposure was set to 'Auto', focus was set to 'Infinity/Manual', and 'Standard Play' mode was selected to provide at least $45 \mathrm{~min}$ of filming at the seabed (mean $\pm \mathrm{SD} ; 53.3 \pm 11.3 \mathrm{~min}$ ). Detachable bait arms (20 mm plastic conduit) had a $350 \mathrm{~mm}$ plastic

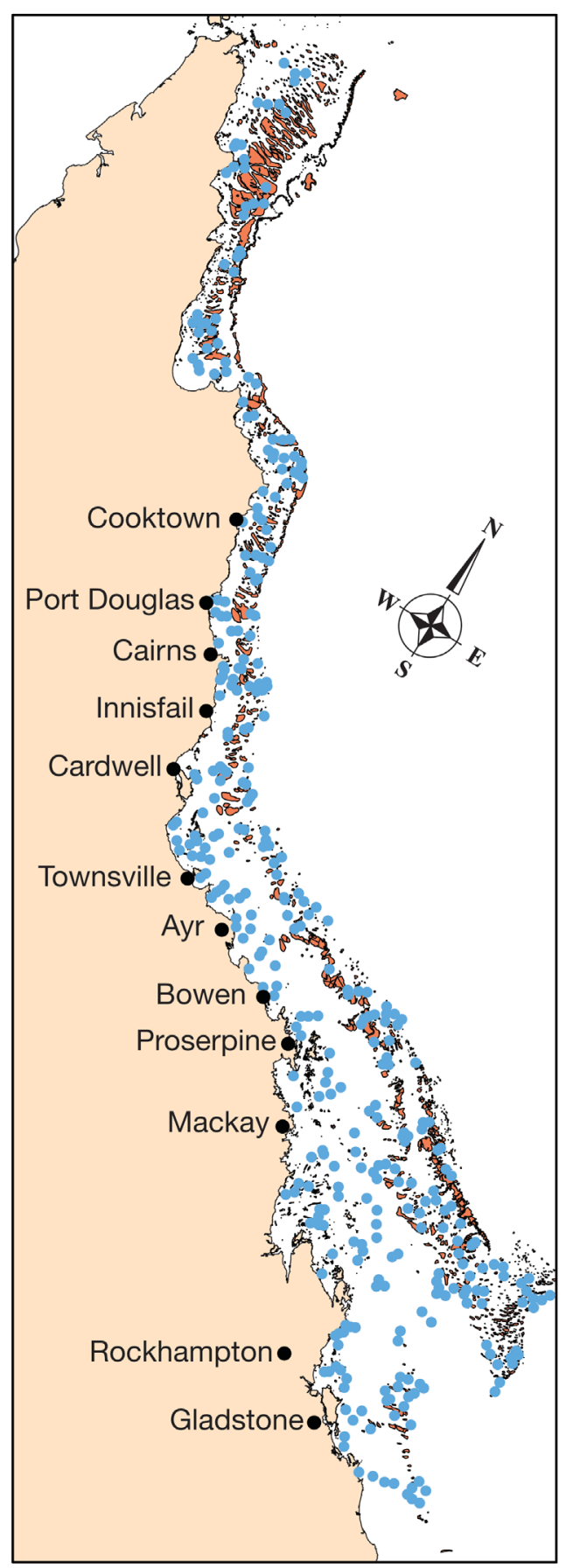

Fig. 1. Rotated map of the Great Barrier Reef Marine Park (GBRMP) showing locations of 366 baited remote underwater video station (BRUVS) sampling sites $(\bullet)$ and the reef matrix 


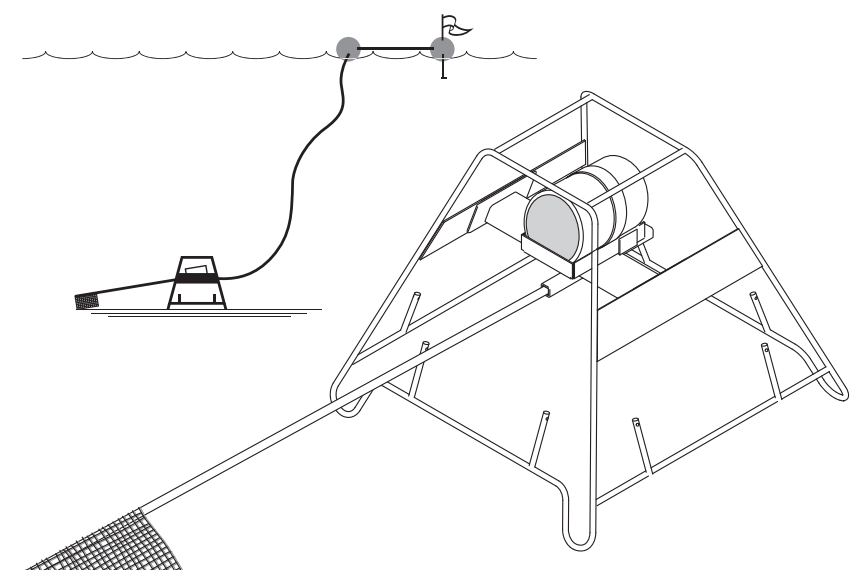

Fig. 2. Baited remote underwater video station (BRUVS) showing deployment on the seabed and details of the removable bait arm, plastic camera housing and pegs for placement of ballast on the frame

mesh canister containing $1 \mathrm{~kg}$ of crushed oily sardines (Sardinops or Sardinella spp.) as bait, lying on the seabed (Fig. 2). BRUVS were deployed with $8 \mathrm{~mm}$ polypropylene ropes and polystyrene surface floats bearing a marker flag, and were retrieved with an hydraulic pot-hauler wheel.

Interrogation of each tape was conducted using a custom interface (BRUVS1.5.mdb, Australian Institute of Marine Science, 2006) to manage data from field operations and tape reading, to capture the timing of events and to capture reference images of the seafloor and fish in the field of view. Records were made for each species of the maximum number seen together at any one time on the whole tape $(\operatorname{Max} N)$. The use of $\operatorname{Max} N$ as an estimator of relative abundance has been reviewed in detail by Cappo et al. $(2003,2004)$. Species identifications were confirmed by checking the collection of reference images with taxonomists, and $14 \%$ of the records were subsequently pooled in 'taxa' at the level of species group, genus, family, or order. These taxa are hereafter referred to as species. Data were analysed at the level of individual sites by summing the replicate $\operatorname{Max} N$ for each species and transforming them by fourth root. The 'locations' of the sites were defined by mean depth and relative distance across and along the GBRMP (Fabricius \& De'ath 2001). Distance across was set to the value 0 on the coast and 1 on the outermost edge of the continental shelf $(80 \mathrm{~m}$ isobath), and distance along the shelf takes the value 0 on the southern edge of the GBRMP and 1 on the northern edge (Fig. 3).

Data analysis. The dependence of site richness on location and depth was assessed using boosted trees (Friedman 2001, Leathwick et al. 2006, De'ath 2007). The transformed estimates of relative abundance $(\operatorname{Max} N)$ of the observed species were analysed using multivariate regression trees (MRT; De'ath 2002). Dufrêne-Legendre index values (DLI; Dufrêne \& Legendre 1997) were then calculated for each species for each node of the tree. For each species and group of sites, the DLI is defined as the product of the mean species abundance occurring in the group divided by the sum of the mean abundances in all other groups, times the proportion of sites within the group where the species occurs, multiplied by 100. Each species was associated with the tree node where its maximum DLI value occurred. High DLI values were used to characterise representatives of each community, and the spatial extent of the group indicated the region where the species was predominantly found (see DeVantier et al. 2006 for further details). All analyses used the R statistical package (R Development Core Team 2005), including the packages gbm, fields, mvpart and vegan.

\section{RESULTS}

The final dataset consisted of 366 sites and 39989 individuals from 347 species of vertebrates. The bony fishes were from 10 Orders, dominated by Perciformes (267 species), Tetraodontiformes (27), Anguilliformes (6), Aulopiformes (3), Scorpaeniformes, Clupeiformes, Beryciformes with 2 species, and Siluriformes, Pleuronectiformes and Gasterosteiformes each with a single species. The chondrichthyians were well represented by the Carcharhiniformes (15 species), Rajiformes (13) and Orectolobiformes (3). There were 5 species of sea snakes from the Family Hydrophiidae.

\section{Species richness}

There was an average $( \pm \mathrm{SD})$ of $13.8 \pm 6$ species site $^{-1}$, ranging from 2 to 43 . Most vertebrates were rare or uncommon, occurring in only a very small percentage of the sites surveyed. Ordering of the most diverse sites produced a sigmoidal curve (Fig. 4a), showing $\sim 14 \%$ of sites had comparatively high species richness ( $\geq 20$ species), $\sim 41 \%$ had moderate richness $(\geq 13$ species), and $18 \%$ had relatively low richness ( $\leq 8$ species). Just over $90 \%$ of the species were recorded in $<10 \%$ of the sites, and $\sim 43 \%$ were recorded only 1 to 3 times (Fig. 4 b). Only $\sim 5 \%$ of the species were moderately prevalent, occurring in $\geq 20 \%$ of the sites, and only Nemipterus furcosus had a prevalence $>50 \%$. General patterns in species richness interpolated by latitude and longitude showed that cross-shelf and along-shore gradients were not simple (see Fig. 8a). Higher richness occurred at sites in the outer reef matrix, particularly north of Proserpine $\left(20.4^{\circ} \mathrm{S}\right)$, with a 'hotspot' off Cape Flattery $\left(15^{\circ} \mathrm{S}\right)$ in the far north. Richness in the 

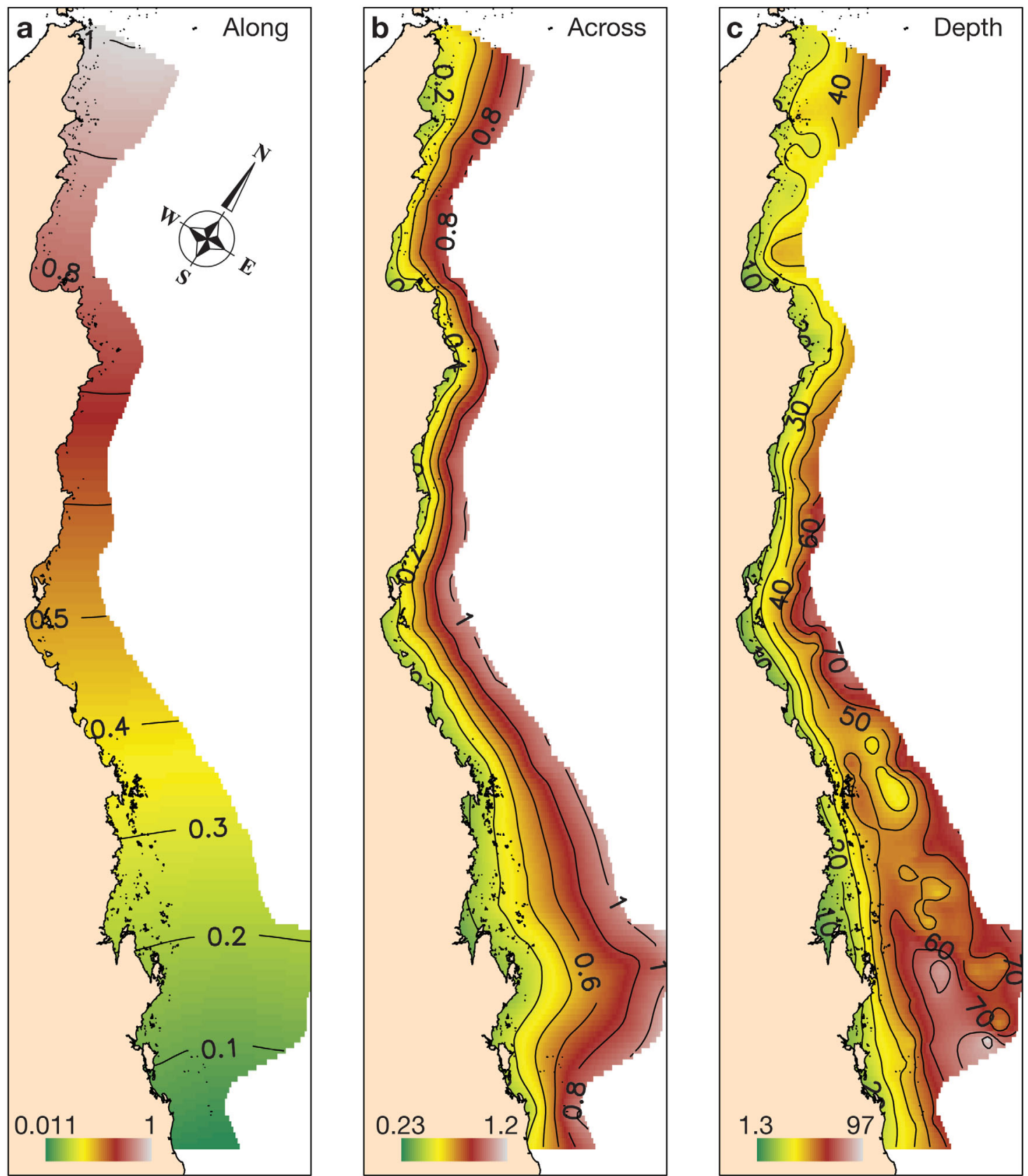

Fig. 3. Patterns (contours and colour shading) of variation of (a,b) location (dimensionless) and (c) depth (m) across and along the shelf for the study area (rotated), smoothed using thin plate splines. Distance along was set to range from 0 at the southern end to 1 at the far northern end. Distance across was 0 on the coast and 1 on the $80 \mathrm{~m}$ isobath. The corners of the polygon formed in this way were at $142.53^{\circ} \mathrm{E}, 10.69^{\circ} \mathrm{S} \& 144.06^{\circ} \mathrm{E}, 10.68^{\circ} \mathrm{S}$ at the northern end and $152.49^{\circ} \mathrm{E}, 25.00^{\circ} \mathrm{S} \& 152.90^{\circ} \mathrm{E}, 24.22^{\circ} \mathrm{S}$ at the southern end

southern half of the GBRMP was higher around the Capricorn-Bunker $\left(23.5^{\circ} \mathrm{S}\right)$ island group, and consistently lower for the coastal bays, the deep mid-shelf waters of the Capricorn trough $\left(\geq 22.5^{\circ} \mathrm{S}\right)$, and the inter-reef waters of the outer barrier reefs (see Fig. 8a).

Cross-shelf position and depth had the greatest influence on richness, which increased monotonically in response to relative distance along the shelf from the southern boundary (Fig. 5). Richness increased across the shelf, with a sharp peak occurring at $\sim 0.8$, where sites had $\sim 3$ more species on average than elsewhere. This isopleth coincides with the mid-shelf reef matrix south of Cardwell $\left(18.25^{\circ} \mathrm{S}\right)$ and the outer barrier reef north of Cardwell (Fig. 3). A modal relationship showed peak richness for depths in the 30 to $35 \mathrm{~m}$ range (Fig. 5d), in the lagoon and on the 

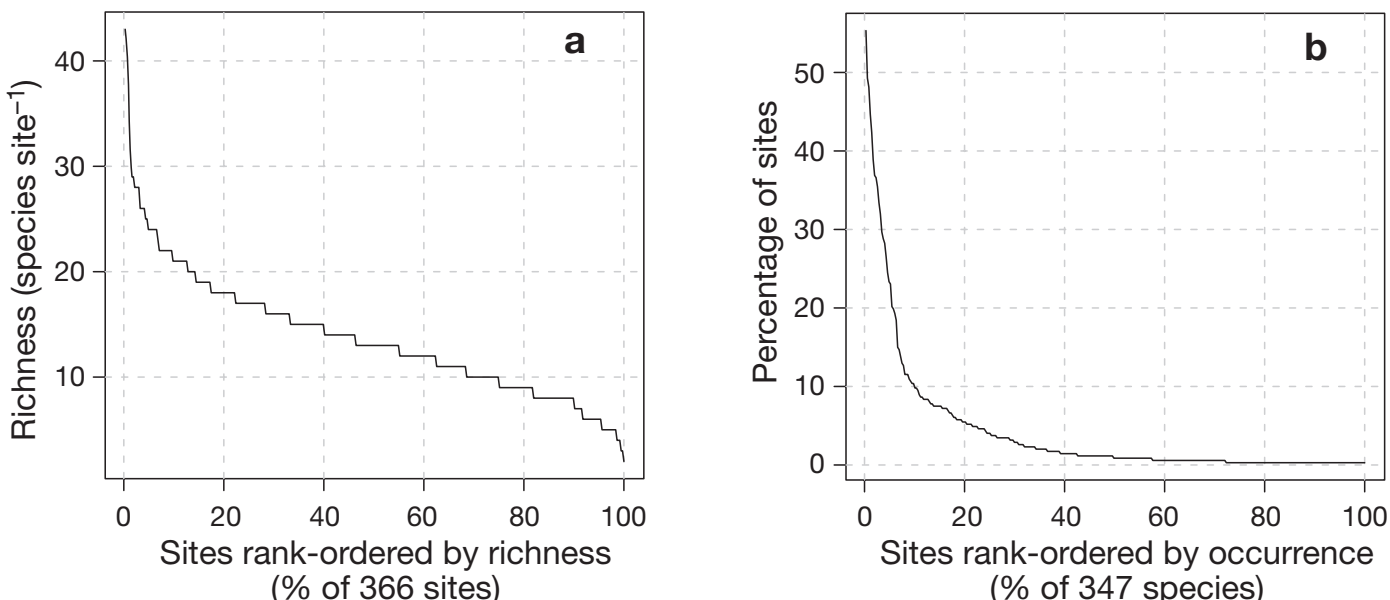

Fig. 4. Summaries of (a) species richness by cumulative number of sites, and (b) prevalence of 347 species, at 366 BRUVS sites ranked in descending order of occurrence

banks and shoals amongst the reef matrix (Fig. 3). The average decline in richness beyond depths of $\sim 35 \mathrm{~m}$ was about 0.1 species $\mathrm{m}^{-1}$.

The first-order interactions showed that cross-shelf increase in richness was most pronounced for shallower sites $\sim 35 \mathrm{~m}$, but the peak in richness at $\sim 0.8$ occurred for all depths. There was a slight decline in richness with increasing distance across the shelf for sites deeper than $50 \mathrm{~m}$ (Fig. 6a). The decline in richness for depths $>35 \mathrm{~m}$ was most pronounced for sites at cross-shelf positions offshore from $\sim 0.6$, coinciding with the inner edge of the reef matrix south of Cardwell and the offshore reef matrix north of Cardwell (Fig. 3). There was also a considerably higher rate of northward increase in species richness at sites within the inter-reef waters $\sim 0.8$ across the shelf (Fig. 6b).

\section{Patterns in vertebrate communities}

Hierarchical vertebrate communities were defined by MRT constrained by location and depth of the sites. A tree with 9 terminal nodes was selected to represent the most parsimonious community structure in similar species composition (Fig. 7). The tree explained $28 \%$ of the variation in the transformed species abundance data-not unusual for datasets containing large numbers of species occurring with low abundance (DeVantier et al. 2006). a
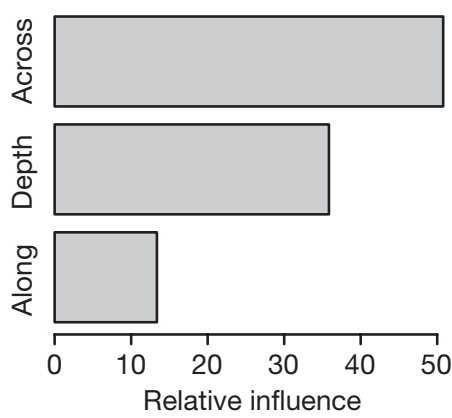

C

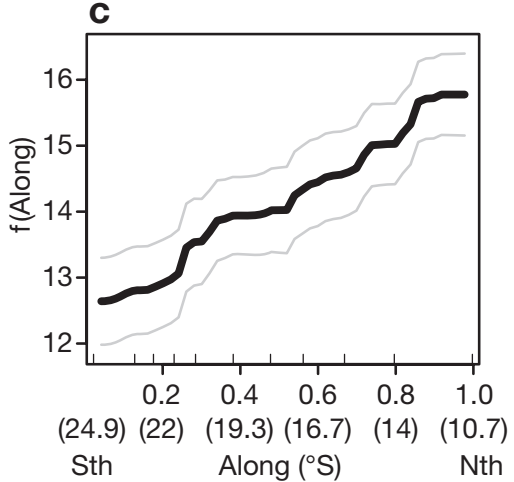

Fig. 5. (a) Relative influence of location and depth as predictors of species richness in a gradient boosting model, and dependency of site species richness on $(b, c)$ location and (d) depth. Richness was constrained to increase monotonically in response to distance along the shelf. Distance along the shelf ranges from 0 at the southern end of the GBRMP to 1 at the far northern end with corresponding latitudes shown in brackets. Distance across takes the value 0 on the coast and 1 on the $80 \mathrm{~m}$ isobath. The tick marks above the $x$-axes indicate the 10 percentiles in location of the BRUVS sites. Values were predicted for each variable, controlling for the effects of both other variables. Grey lines indicate $\pm 2 \mathrm{SE}$ for the predicted values, estimated from predictions made from 500 trees fitted in 5 -fold cross validation of the BRUVS dataset 

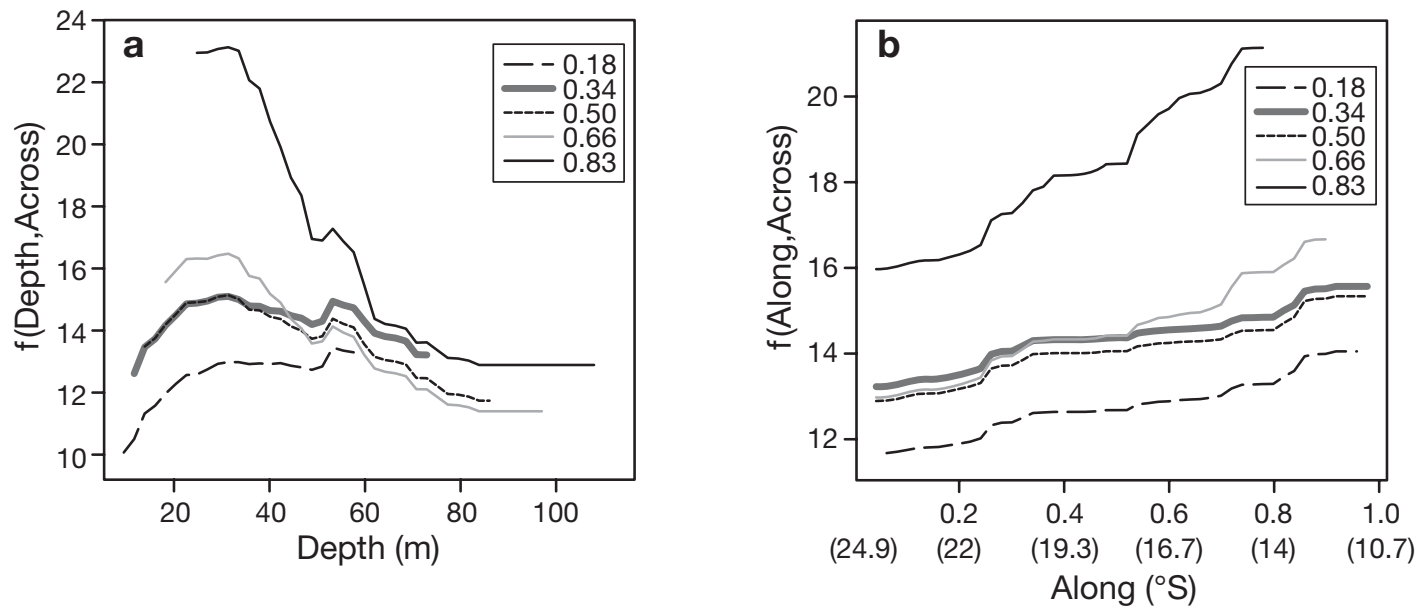

Fig. 6. Partial dependency of site species richness at 5 distances across the shelf (a) on depth and (b) on the distance along the shelf. Other conventions described in Fig. 5

The primary split separated inshore and offshore groups at $\sim 0.5$ half-way across the shelf. This isopleth lies in the open waters of the lagoon in the southern half of the GBRMP, south of Cardwell, and in the reef matrix in the northern half. The next splits distinguished shallow and deep groupings on either side of the $\sim 36 \mathrm{~m}$ isobath within each of these regions. Within the inshore side of the tree, the lower level splits were all based on distances along the shelf. The inshore node split into groups north and south of Cape Flattery (along $\sim 0.74$ ), with 4 terminal groups north and south of the top of the Whitsunday islands, near Bowen $\left(20^{\circ} \mathrm{S}\right.$ ) (along $\left.\sim 0.37\right)$. The offshore side of the tree included nodes separating the deeper sites amongst

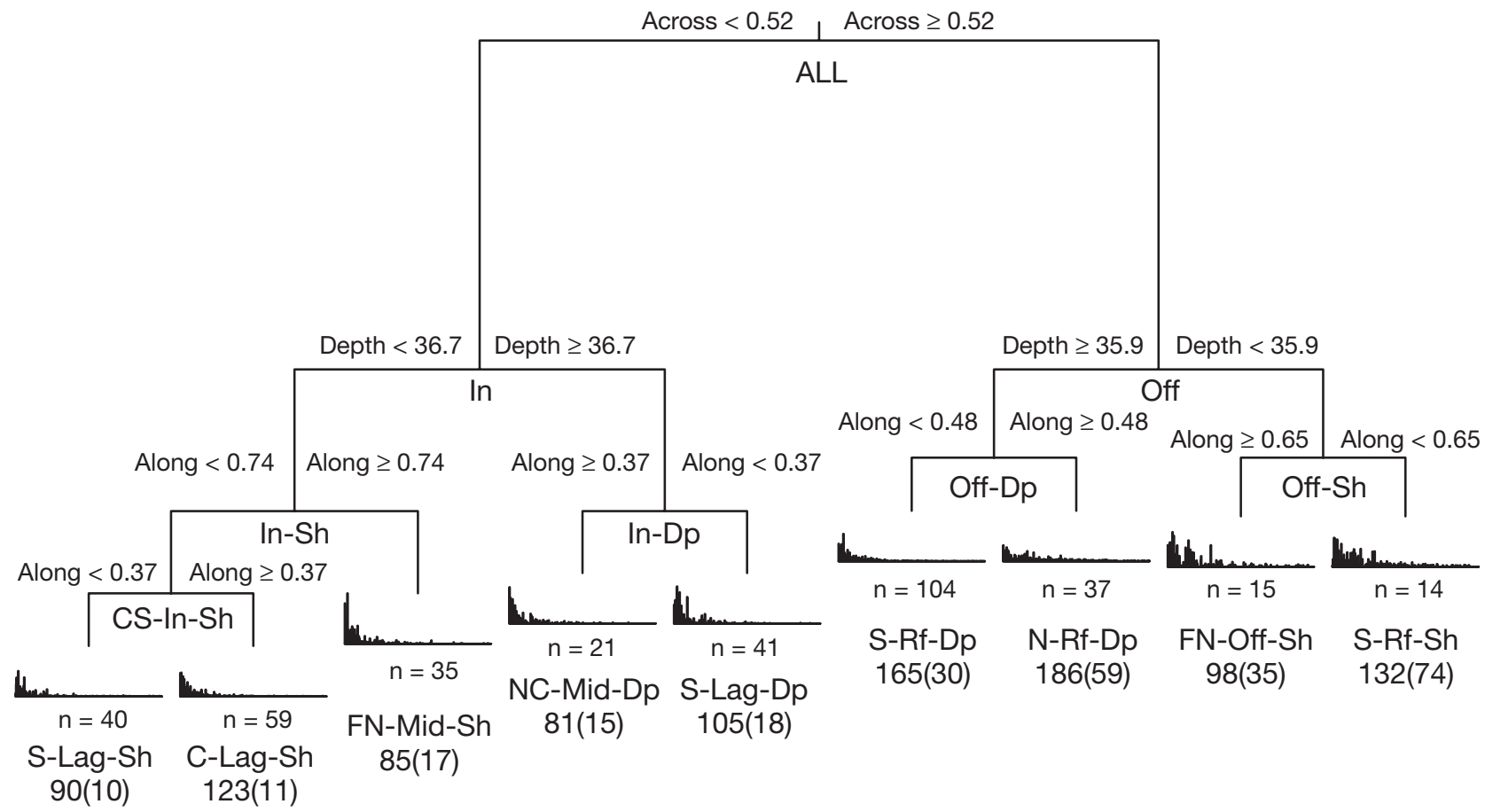

Fig. 7. Multivariate regression tree analysis defining transformed relative abundance of vertebrate communities in terms of location and depth. The terminal nodes represent 9 communities inshore (In) and offshore (Off) in the far north (FN), north (N), central (C), south (S), shallow (Sh), deep (Dp), lagoon (Lag), mid-shelf (Mid) and inter-reef (Rf) regions (see Fig. 8 for locations). The higher level nodes represent the 8 communities at higher spatial scales in these regions. The bar plots show the distribution of mean species abundances at each of the terminal nodes, ranked from left to right in decreasing order of prevalence in the entire dataset, with the number of sites within each group (n). Species richness in terminal groups is shown next to the number of indicator species, with maximum Dufrêne-Legendre index values in brackets 
the reef matrix north and south of Magnetic Passage off Townsville $\left(18.5^{\circ} \mathrm{S}\right.$ ) (along $\sim 0.48$ ), and north and south of Port Douglas $\left(16.5^{\circ} \mathrm{S}\right)$ (along $~ 0.65$ ) at depths of $<36 \mathrm{~m}$.

The location of BRUVS sites within the 9 terminal tree groupings was described by deep and shallow groupings in the far north (FN), central (C) and southern (S) regions of the GBRMP. Within these regions the lagoon (Lag), mid-shelf (Mid) and inter-reef (Rf) waters of the reef matrix can be recognised (Fig. 8b,c). Latitudinal variation was greatest inshore in the lagoon, with 3 shallow communities separated in the north off Cape Flattery and in the south off Bowen (FN-Mid-Sh, C-Lag-Sh, S-Lag-Sh), and 2 deep lagoon communities on either side of Bowen (S-Lag-Dp, NC-Mid-Dp). Sites in the groups offshore amongst the reef matrix also split based on the location along the shelf. Shallow-water groups occurred on shoals and banks in the reef matrix, north of Cape Flattery (FN-Off-Sh) and south of Cairns (S-Rf-Sh). Deeper sites in the passages and plains between the reefs split
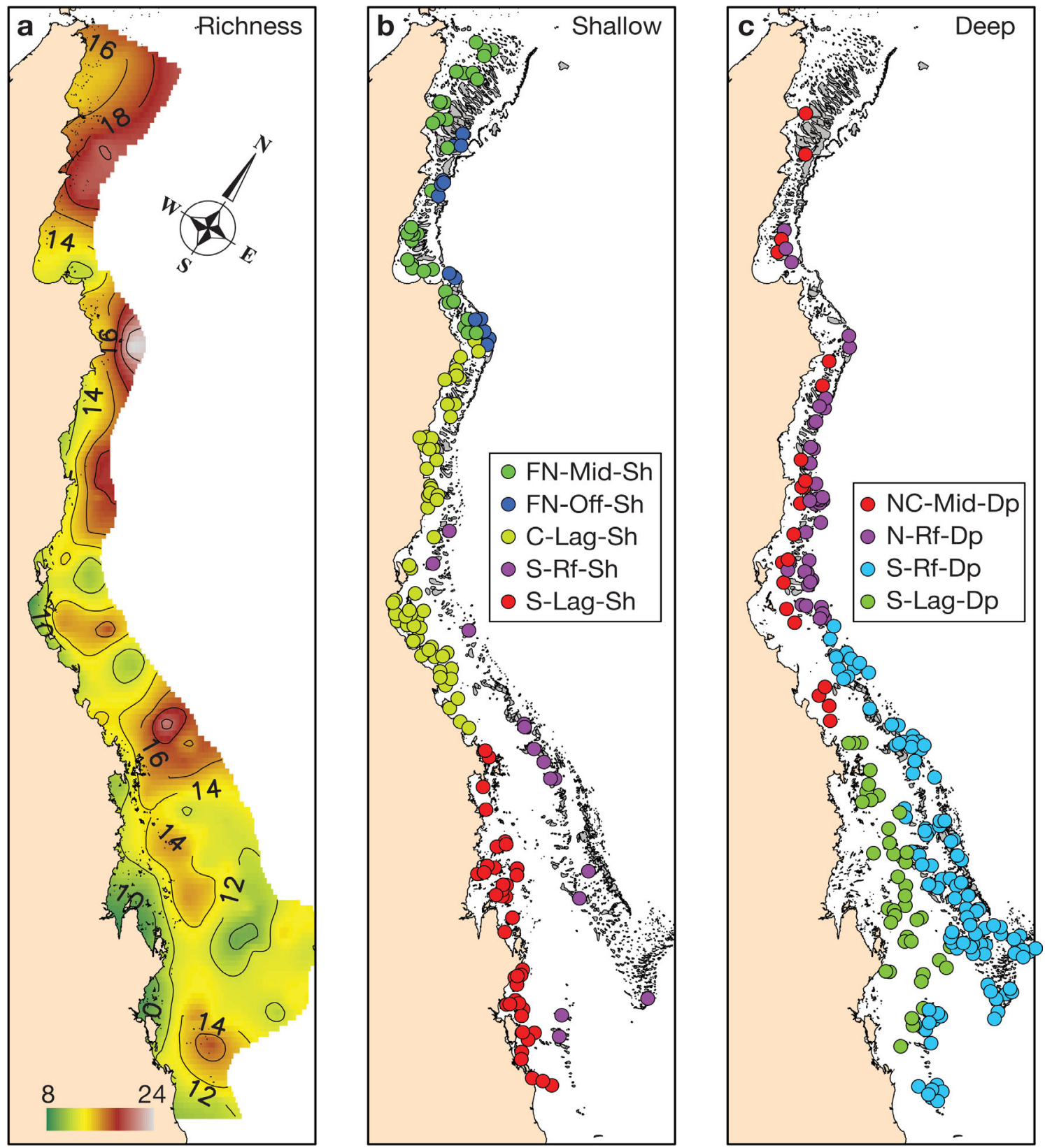

Fig. 8. Model of (a) species richness interpolated for the study area (rotated) with a smoothed thin plate spline technique and $(\mathrm{b}, \mathrm{c})$ location of sites within the 9 vertebrate community groups divided into shallow and deep groups within regions of the GBRMP (rotated). See Fig. 7 for community abbreviations 
into 2 extensive offshore groups north (N-Rf-Dp) and south (S-Rf-Dp) of Magnetic Passage off Townsville.

Most species were rare in each group, but the majority of the few prevalent species had consistently higher abundances in the 2 shallow offshore groups (FN-OffSh and S-Rf-Sh) (Fig. 7). Less than $3 \%$ of species had a high DLI $(\geq 50)$, and most of these occurred in 4 dominant, higher level community nodes (Tables 1 \& 2, Fig. 7). Only $12 \%$ of species had moderately high DLI values (between 20 and 50), and more than half of these occurred in the terminal groups, most notably the offshore, shallow nodes. There were only 29 sites $(8 \%)$ in the S-Rf-Sh and FN-Off-Sh groups, yet they dominated the analysis of DLI values for $>36 \%$ of all species (Fig. 7), mostly in the families known to associate with complex seabed topography (Table 2). In contrast, C-Lag-Sh and S-Rf-Dp contained no indicator species with moderate values. The largest terminal group (S-Rf-Dp) in the tree had $28 \%$ of the sites and $47 \%$ of the recorded species, yet abundances were generally very low and none had moderately high DLI values there. Such groups were dominated by others in spatial hierarchy, in the sense that all their species members also occurred in higher numbers elsewhere. The 17 indicator species with DLI maxima at the root node were generally ubiquitous, abundant and widely distributed (Table 1).

The most striking groupings were S-Rf-Sh and FNOff-Sh, within the shallow offshore side of the treecomprising only $8 \%$ of all sites, but including $>51 \%$ of all species and DLI maxima for $>31 \%$ of all species. Sites in these communities had the highest richness and higher abundance than most other terminal groups (Table 2). Species accumulation curves in these 2 moderately rich communities showed the fastest rates of increase and no sign of reaching an asymptote (Fig. 9). The richest community (N-Rf-Dp) comprising a moderate number of sites also had a relatively high rate of species accumulation. The other 7 communities showed lower species accumulation rates, and only the group with the largest number of sites (S-Rf-Dp) showed strong curvature toward an asymptote in species richness (Fig. 9). These trends indicate that the sampling effort had not produced a comprehensive representation of species diversity within most of the communities.

\section{DISCUSSION}

Significant ecological differences have been reported in the GBRMP, along the strong cross-shelf gradients readily measurable in riverine outflow, nutrient input, water clarity and exposure to prevailing wind and waves (e.g. Wilkinson \& Cheshire 1988, Newman et al. 1997, Drew 2001). Few studies have incorporated the latitudinal gradient along the shelf (Williams 1991, Fabricius \& De'ath 2001, DeVantier et al. 2006), and most have been restricted to the depth limits of SCUBA diving observations on shallow reefs. The results reported here

Table 1. Summaries of richness in the 8 higher order fish communities. Details of all species with moderate to high values of the Dufrêne-Legendre index (DLI $\geq 20$ ), or only the top 5 indicator species, within each site group are shown with DLI in parentheses. For a given species and a given group of sites, the DLI is defined as the product of the mean species abundance occurring in the group divided by the sum of the mean abundances in all other groups (specificity), multiplied by the proportion of sites within the group where the species occurs (fidelity), multiplied by 100. See Fig. 7 for community abbreviations

\begin{tabular}{|c|c|c|}
\hline $\begin{array}{c}\text { Node no./ } \\
\text { grouping }\end{array}$ & $\begin{array}{l}\text { No. of sites } \\
\text { (species) }\end{array}$ & Indicator species (DLI) \\
\hline 1 All & $366(347)$ & $\begin{array}{l}\text { Nemipterus furcosus (52), Echeneis naucrates (47), Abalistes stellatus (40), Pentapodus } \\
\text { paradiseus (37), Lagocephalus sceleratus (34), Carangoides fulvoguttatus (27) }\end{array}$ \\
\hline 2 In & $196(187)$ & $\begin{array}{l}\text { Scomberomorus queenslandicus (64), Selaroides leptolepis (56), Nemipterus hexodon (40), } \\
\text { Carangoides coeruleopinnatus (34), Gymnothorax minor (29), Nemipterus peronii (21) }\end{array}$ \\
\hline 3 Off & $170(295)$ & $\begin{array}{l}\text { Pentapodus nagasakiensis (51), Lutjanus sebae (15), Parupeneus heptacanthus (14), Pristotis } \\
\text { obtusirostris (14), Galeocerdo cuvier (10), Loxodon macrorhinos (10) }\end{array}$ \\
\hline 4 In-Sh & $134(167)$ & Paramonacanthus otisensis (36), Carangoides hedlandensis (21), Lutjanus carponotatus (2) \\
\hline 5 In-Dp & $62(124)$ & $\begin{array}{l}\text { Nemipterus theodorei (53), Seriolina nigrofasciata (51), Saurida grp. (43), Decapterus russelli } \\
\text { (38), Lutjanus malabaricus (10) }\end{array}$ \\
\hline 6 Off-Dp & $141(256)$ & $\begin{array}{l}\text { Carcharhinus albimarginatus (12), Pleuronectiformes grp. (7), Arothron stellatus (3), Pen- } \\
\text { tapodus sp. (3), Chaetodon auriga (2) }\end{array}$ \\
\hline 7 Off-Sh & $29(177)$ & $\begin{array}{l}\text { Pentapodus aureofasciatus (38), Parupeneus barberinoides (36), Symphorus nematophorus } \\
\text { (35), Lethrinus genivittatus (31), Lethrinus semicinctus (28), Upeneus tragula grp. (25), } \\
\text { Gnathanodon speciosus (24), Nebrius ferrugineus (22) }\end{array}$ \\
\hline 8 CS-In-Sh & $99(151)$ & Herklotsichthys lippa (2), Pomadasys kaakan (2) \\
\hline
\end{tabular}


are the first attempt at describing the patterns in vertebrate communities in terms of both the horizontal crossshelf and along-shelf gradients and the third, vertical dimension of the full range of shelf depths.
The use of boosted and multivariate regression trees has provided compelling results concerning the crossshelf rise in species richness in the lagoon and amongst the reef matrix, the existence of spatially contiguous

Table 2. Summaries of mean, standard deviation and range of richness and abundance (abund.) in the 9 terminal fish communities. Details of species with moderate to high values of the Dufrêne-Legendre index (DLI $\geq 20$ ), or only the top 5 indicator species, within each site group are shown with DLI in brackets. See Fig. 7 for community abbreviations

\begin{tabular}{|c|c|c|c|c|}
\hline $\begin{array}{l}\text { Node no./ } \\
\text { grouping }\end{array}$ & $\begin{array}{l}\text { No. of } \\
\text { sites } \\
\text { (species) }\end{array}$ & $\begin{array}{l}\text { Richness: } \\
\text { mean } \pm \mathrm{SD} \\
\text { (range) }\end{array}$ & $\begin{array}{l}\text { Raw abund.: } \\
\text { mean } \pm \mathrm{SD} \\
\text { (range) }\end{array}$ & Indicator species (DLI) \\
\hline 10 NC-Mid-Dp & $21(81)$ & $\begin{array}{l}14.5 \pm 2.9 \\
(8 \text { to } 21)\end{array}$ & $\begin{array}{l}197 \pm 326 \\
(19 \text { to } 1485)\end{array}$ & $\begin{array}{l}\text { Scolopsis taeniopterus (21), Aipysurus laevis (20), Nemipterus } \\
\text { nematopus (15), Paramonacanthus lowei (14), Sphyraena jello (8) }\end{array}$ \\
\hline 11 S-Lag-D & 41 (105) & $\begin{array}{l}15.4 \pm 4.6 \\
(8 \text { to } 26)\end{array}$ & $\begin{array}{l}115 \pm 56 \\
(39 \text { to } 233)\end{array}$ & $\begin{array}{l}\text { Paramonacanthus filicauda (63), Carangoides malabaricus grp. } \\
\text { (28), Caranx bucculentus (18), Terapon jarbua (12), Pristipomoides } \\
\text { multidens (8) }\end{array}$ \\
\hline 12 S-Rf-Dp & $104(165)$ & $\begin{array}{l}11.8 \pm 5.3 \\
(3 \text { to } 29)\end{array}$ & $\begin{array}{l}93 \pm 75 \\
(10 \text { to } 585)\end{array}$ & $\begin{array}{l}\text { Upeneus filifer (11), Oxycheilinus celebicus (4), Halichoeres sp. } \\
\text { (4), Thalassoma amblycephalum (3), Coris picta (3) }\end{array}$ \\
\hline 13 N-Rf-Dp & 37 (186) & $\begin{array}{l}15.7 \pm 8.3 \\
(3 \text { to } 42)\end{array}$ & $\begin{array}{l}63 \pm 29 \\
(19 \text { to } 155)\end{array}$ & $\begin{array}{l}\text { Gymnocranius grandoculis (26,) Nemipterus balinensoides grp. } \\
\text { (17), Pristipomoides typus (14), Lutjanus bohar (11), Epinephelus } \\
\text { cyanopodus (11) }\end{array}$ \\
\hline 9 FN-Mid-Sh & $35(85)$ & $\begin{array}{l}14.7 \pm 3.4 \\
(8 \text { to } 23)\end{array}$ & $\begin{array}{l}183 \pm 219 \\
(60 \text { to } 1290)\end{array}$ & $\begin{array}{l}\text { Atule mate (26), Carcharhinus tilstoni grp. (23) Alepes apercna } \\
\text { (23), Lagocephalus grp. (13), Choerodon cephalotes (10) }\end{array}$ \\
\hline 14 FN-Off-Sh & $15(98)$ & $\begin{array}{l}19.3 \pm 6 \\
(6 \text { to } 28)\end{array}$ & $\begin{array}{l}164 \pm 129 \\
(25 \text { to } 525)\end{array}$ & $\begin{array}{l}\text { Amblypomacentrus breviceps (66), Oxycheilinus bimaculatus } \\
\text { (56), Paramonacanthus japonicus (54), Aprion virescens (20), } \\
\text { Himantura fai grp. (20), Meiacanthus grammistes (20), } \\
\text { Choerodon gomoni (20) }\end{array}$ \\
\hline 15 S-Rf-Sh & $14(132)$ & $\begin{array}{l}22.9 \pm 9.1 \\
(10 \text { to } 43)\end{array}$ & $\begin{array}{l}127 \pm 77 \\
(25 \text { to } 262)\end{array}$ & $\begin{array}{l}\text { Choerodon venustus (48), Lethrinus miniatus (48), Parapercis } \\
\text { xanthozona grp. (48), Pomacentrus nagasakiensis (44), Lethrinus } \\
\text { ravus (43), Pomacentrus australis (39), Gymnocranius audleyi (32), } \\
\text { Chaetodontoplus meredithi (32), Plectropomus leopardus (23), } \\
\text { Chrysiptera rollandi (21) }\end{array}$ \\
\hline 16 S-Lag-Sh & $40(90)$ & $\begin{array}{l}10.4 \pm 3.9 \\
(2 \text { to } 21)\end{array}$ & $\begin{array}{l}74 \pm 63 \\
(17 \text { to } 355)\end{array}$ & $\begin{array}{l}\text { Platycephalidae grp. (22), Pomadasys maculatus (5), Sillago grp. } \\
\text { (3), Aluterus monoceros (3), Chaetodontoplus duboulayi (3) }\end{array}$ \\
\hline 17 C-Lag-Sh & $59(123)$ & $\begin{array}{l}12.8 \pm 4.8 \\
(4 \text { to } 28)\end{array}$ & $\begin{array}{l}94 \pm 146 \\
(6 \text { to } 1096)\end{array}$ & $\begin{array}{l}\text { Carangoides talamparoides grp. (13), Lapemis hardwickii (9), } \\
\text { Apogon kiensis (2), Epinephelus malabaricus (2), Heniochus } \\
\text { acuminatus (2) }\end{array}$ \\
\hline
\end{tabular}
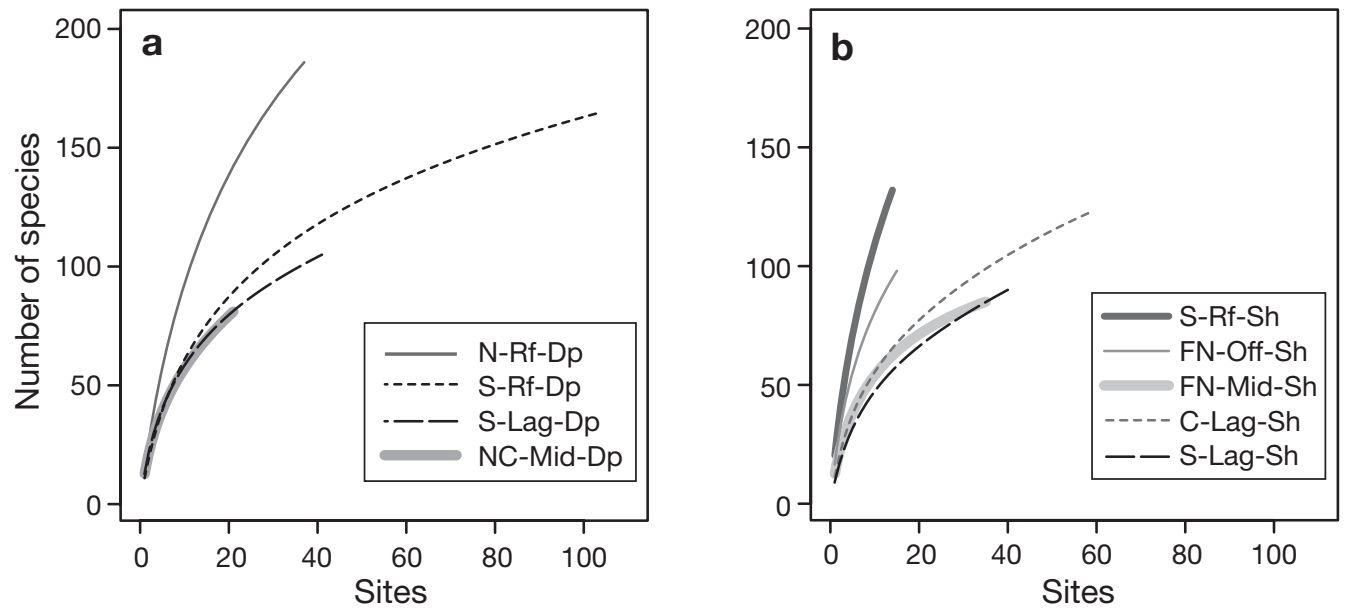

Fig. 9. Species-accumulation curves for the (a) 4 deep and (b) 5 shallow regional communities. See Fig. 7 for community abbreviations 
vertebrate communities along and across the shelf, and the existence of community boundaries near Bowen $\left(20^{\circ} \mathrm{S}\right)$ in the south, Townsville $\left(18.5^{\circ} \mathrm{S}\right)$ in the central section, and Port Douglas $\left(16.5^{\circ} \mathrm{S}\right)$ and Cape Flattery $\left(15^{\circ} \mathrm{S}\right)$ in the north. These robust patterns were detected amongst a functionally diverse cross-section of the aquatic vertebrate fauna by a simple, efficient baited video technique without disturbing seafloor habitats or harming the fauna.

\section{Spatial trends in species richness}

Cross-shelf position and depth had the greatest influence in predicting species richness, which increased with distance across the shelf to a sharp peak, $\sim 0.8$ where coral reefs exist and sites had about 4 species above average. A modal relationship predicted peak richness for depths in the 30 to $35 \mathrm{~m}$ range, in the lagoon and banks and shoals amongst the reef matrix, followed by a decline of about 1 species for each $10 \mathrm{~m}$ increase in depth. The position of this isobath across the shelf varied as the lagoon and reef matrix generally taper in width from south to north. The habitats at these depths are poorly known, but include vast Halimeda algal banks (Drew 2001) and deep-water seagrass in the lagoon (Carruthers et al. 2002). The weak northward increase in species richness of about 1 species for every $3^{\circ}$ of latitude was expected, given general patterns in aquatic species diversity (Gray 2001) and previous studies in the GBRMP (DeVantier et al. 2006). The interactions amongst the northward, cross-shelf rise in richness and the modal influence of depth indicated lower diversity for a given depth in the deeper gutters, passages and inter-reef plains between the reefs.

It is possible that mid-shelf peaks in species richness might arise through simple geometric overlap of range boundaries of nearshore and offshore species assemblages in the absence of any environmental gradients. This is termed the 'mid-domain effect' (Colwell et al. 2004), and might explain why highest richness was interpolated for the localised region offshore of Cape Flattery, where sampling sites in close proximity were separated into 5 species communities.

Most species were rare and species accumulation curves approached an asymptote for only a single community group, implying that full representation of the diversity of most communities will require more sampling. The richer communities had low inflection points on the ordinate axis and a long upward slope toward an asymptote - a curve shape characteristic of faunas with a high proportion of rare species and a few abundant species (Magurran \& Henderson 2003, Thompson \& Withers 2003). This pattern seems charac- teristic of tropical fish faunas sampled by trawl, as Stobutzki et al. (2001) found that $75 \%$ of species occurred in $<10 \%$ of prawn trawls, and Blaber et al. (1994) found that $75 \%$ of the biomass in fish trawls was composed of only $8 \%$ of the species caught. Like estuarine fish faunas (Magurran \& Henderson 2003), the vertebrates in the inter-reef waters of the GBRMP probably comprise 'core species', which are persistent, abundant and biologically associated with particular habitats, and 'occasional species', which occur infrequently in surveys, are typically low in abundance and have different habitat requirements.

\section{Shelf-scale patterns in vertebrate communities}

The multivariate trees were used to define a hierarchy of groups of species that co-occur at varying spatial scales to form communities. This contrasts with nonhierarchical methods (such as K-means clustering), which derive mutually exclusive clusters at a single spatial scale, thereby lacking information at broad spatial scales and not highlighting information from highly prevalent species (De'ath 2007).

Shallow and deep communities on either side of the 35 m isobath were distinguished along strong crossshelf and latitudinal gradients. Latitudinal variation was greatest in the inner half of the shelf, where Bowen and Cape Flattery separated 3 shallow innershelf groups and 2 deep mid-shelf communities. The offshore communities were latitudinally more extensive, but still split into a northern and a southern group, showing that outer-shelf deep communities were more similar amongst latitudes than to mid-shelf deep communities at the same latitude and vice versa. The mid-shelf sites north of Cape Flattery showed closer similarity to the nearshore sites to the south than they did to the mid-shelf sites elsewhere. Both these trends were similar to the patterns found by Williams (1991) for coral reef fish communities, for which midshelf reefs in the far north were more similar to nearshore reefs elsewhere than to mid-shelf reefs at more southerly latitudes.

Cross-shelf gradients in tropical, demersal fish communities away from reefs have been reported previously in the Indo-Pacific and the Atlantic in relation to faunal provinces (Ramm et al. 1990), cross-shelf location (Watson et al. 1990, Letourneur et al. 1998), depth (Ramm et al. 1990, Blaber et al. 1994), sediment type (Longhurst \& Pauly 1987), epibenthic cover (Sainsbury et al. 1997) and the location of thermoclines (Fager \& Longhurst 1968). Unlike the regular cross-shelf progression of communities dominated by ariids, sciaenids, lutjanids and sparids described for Atlantic shelves (Lowe-McConnell 1987), we did not find simple cross- 
shelf occurrence of different families, and single families often contained a number of species that characterised different communities.

Ubiquitous families such as the nemipterids, monacanthids, carcharhinids and tetraodontids had representatives in both inshore and offshore, deep and shallow communities. The inshore community included many indicator species from the 'small pelagic' functional groups, such as the piscivorous Scomberomorus and small zooplanktivorous carangids (Alepes, Atule, Selaroides and Carangoides). Hydrophid sea snakes, and demersal teraponids and bathysaurids, were also characteristic of inshore groups and are known to inhabit soft sediments elsewhere in the IndoPacific (Blaber et al. 1994, Sainsbury et al. 1997). Indicator species offshore included many representatives of the lutjanids, lethrinids, pomacentrids, dasyatids, mullid, pinguipedids and serranids known to be associated with more complex seafloor topography, such as reefs, rocks and rubble. Deep-water lutjanids and serranids (Pristipomoides, Epinephelus) characterised communities where the deepest water occurred.

\section{Cross-shelf and latitudinal gradients in the GBRMP}

We propose that cross-shelf variation in sedimentary processes and along-shelf variability in oceanic influences shape the boundaries identified here amongst communities. The wide range of inter-reef habitats is dominated in different regions of the GBRMP by combinations of cyclonic events, tides, currents and upwellings, waves, riverine inputs and seasonal winds (Larcombe \& Carter 2004, Porter-Smith et al. 2004). These forces govern the topography, grain size and composition of sediments, the chemical properties of overlying waters and therefore the nature of infaunal, phototrophic or filter-feeding epibenthic communities (e.g. Birtles \& Arnold 1988). In turn, these habitats influence the recruitment, feeding success and mortality of the fish communities inhabiting them (Sainsbury et al. 1997).

There were 3 broad cross-shelf zones in location of the vertebrate communities (Lag, Mid, Off) that can be related in the region south of Cape Flattery to 3 sedimentary belts in seabed composition and topography described by Larcombe \& Carter (2004). They defined a terrigenous prism of bioturbated sand and mud extending to depths of 20 to $22 \mathrm{~m}$, a lagoonal zone (22 to $40 \mathrm{~m}$ ) with mixed shelly, muddy sand and shell hash overlying weathered Pleistocene clay, and an inter-reef zone (40 to $80 \mathrm{~m}$ ), starved of terrigenous sediment, where there are Pleistocene reef remnants amongst detrital carbonate sediments. These zones are maintained through the influence of south-easterly trade winds driving along-shelf drift northward, and by the regular passage of tropical cyclones causing strong northward currents in the lagoon.

The clear latitudinal boundaries between the communities at Bowen, Townsville and Cape Flattery can be related to the configuration of the shelf and reef matrix, currents and tides. Much of the area south of Bowen is macrotidal (to $8.2 \mathrm{~m}$ near $22^{\circ} \mathrm{S}$ ), and PorterSmith et al. (2004) predicted that mobility and grain size properties of the sediment in this region were dominated by tidal currents, in contrast with the rest of the GBRMP. Deep-water seagrasses (mainly Halophila spp.) are known to respond to these gradients. They were reported by Carruthers et al. (2002) to be absent from most of the 'tide-only' region south of Bowen, and to be uncommon north of Cape Flattery, where nutrient or recruitment limitation restricts their abundance. The beds of highest density are known to occur mostly on the inner shelf of the central GBRMP in 15 to $58 \mathrm{~m}$ (Carruthers et al. 2002). Meadows of the alga Halimeda also occur in clear waters, but their richest development, into extensive, 15 to $20 \mathrm{~m}$ thick bioherms, is driven by tidal jetting of nutrients behind the chain of Ribbon reefs north of Port Douglas (Drew 2001).

The westward impingement and bifurcation of the South Equatorial Current (SEC) against the continental shelf peaks in the central region $\left(14\right.$ to $\left.20^{\circ} \mathrm{S}\right)$, providing a further explanation for our community boundaries at Bowen and Cape Flattery. The reef matrix is significantly more 'permeable' in this central section between the Ribbon reefs in the north and the Pompey reefs off Proserpine to the south. The density of barrier reefs is much lower, and the westward flowing SEC readily traverses the numerous passages shoreward in this central region. This direct infiltration of the SEC, as well as regional upwelling induced by the southerly setting East Australian Current (Wolanski 1994), drives an influx of oceanic water across the reef matrix as far as the mid-shelf. The northward flow in the lagoon induced by the trade winds effectively halts this influx, forming a coastal boundary layer (Brinkman et al. 2002). The result is a cross-shelf gradient that isolates nearshore waters from the outer lagoon in the central section, and the formation of 3 different regions of water movement along the GBRMP.

There are also latitudinal gradients in flushing rates and the amplitude of seasonal variation in sea-surface temperature (SST) and salinity. Hancock et al. (2006) found that inner lagoon diffusivity was about 2.5 times higher in the central section compared to in the north, so that water within $20 \mathrm{~km}$ of the coast is flushed with outer lagoon water on a time scale of 18 to $45 \mathrm{~d}$, with the flushing time increasing northwards. Salinities in the southern lagoon are significantly higher than those in the central and northern sections, and seasonal vari- 
ation is lower. Summer SSTs are $\sim 2$ to $3^{\circ} \mathrm{C}$ lower in the region south of Bowen compared to in the region to the far north, and in winter a relatively cold coastal water body forms there (Condie \& Dunn 2006).

\section{CONCLUSIONS}

The cross-shelf patterns we describe in species richness and community groupings fit well with knowledge of gradients and boundaries in sedimentary processes and water circulation patterns in a cooler, macrotidal southern region, a well-flushed central region, and a warmer, constricted northern region. The next step is to analyse these spatial factors with a comprehensive suite of physical and biotic covariates to refine definition of the shelf-scale patterns in communities and their indicator species and to predict their underlying influences.

Acknowledgements. This paper is a product of the 'Great Barrier Reef Seabed Biodiversity Project', a collaboration between the Australian Institute of Marine Science (AIMS), the Commonwealth Scientific and Industrial Research Organisation (CSIRO), the Queensland Department of Primary Industries \& Fisheries (QDPIF), and the Queensland Museum (QM). The project was funded by the CRC Reef Research Centre, the Fisheries Research and Development Corporation and the National Oceans Office, and led by Drs R. Pitcher (Principal Investigator, CSIRO), P. Doherty (AIMS), J. Hooper (QM) and N. Gribble (QDPIF). We thank the multi-agency field teams and the crew of the RV 'Lady Basten' and gratefully acknowledge the development of the BRUVS1.5.mdb software by G. Ericson and G. Coleman (AIMS). H. Sturmey assisted with tape reading, and fish identifications were checked by D. Gledhill (CSIRO) and J. Johnson (QM). The manuscript benefited from the comments of 2 anonymous referees. M.C. is currently being supported in part by the School of Marine and Tropical Biology, James Cook University.

\section{LITERATURE CITED}

Birtles RA, Arnold PW (1988) Distribution of trophic groups of epifaunal echinoderms and molluscs in the soft sediment areas of the central Great Barrier Reef shelf. In: Choat $\mathrm{JH}_{\text {, }}$ Barnes D (eds) Proc 6th Int Coral Reef Symp, Vol 3. Symposium Executive Committee, Townsville, p 325-332

Blaber SJM, Brewer DT, Harris AN (1994) Distribution, biomass and community structure of demersal fishes of the Gulf of Carpentaria, Australia. Aust J Mar Freshw Res 45: 375-396

Brinkman R, Wolanski E, Deleersnijder E, McAllister F, Skirving W (2002) Oceanic inflow from the Coral Sea into the Great Barrier Reef. Estuar Coast Shelf Sci 54:655-668

Cappo M, Harvey E, Malcolm H, Speare P (2003) Potential of video techniques to monitor diversity abundance and size of fish in studies of marine protected areas. In: Beumer JP, Grant A, Smith DC (eds) Aquatic protected areas-What works best and how do we know? Proc World Congr on Aquat Protected Areas. Australian Society for Fish Biology, North Beach, Western Australia, p 455-464
Cappo M, Speare P, D'eath G (2004) Comparison of baited remote underwater video stations (BRUVS) and prawn (shrimp) trawls for assessments of fish biodiversity in interreefal areas of the Great Barrier Reef Marine Park. J Exp Mar Biol Ecol 302(2):123-152

Carruthers TJB, Dennison WC, Longstaff BJ, Waycott M, Abal EG, McKenzie LJ, Lee Long WJ (2002) Seagrass habitats of northeast Australia: models of key processes and controls. Bull Mar Sci 71(3):1153-1169

Colwell RK, Rahbek C, Gotelli NJ (2004) The mid-domain effect and species richness patterns: What have we learned so far? Am Nat 163(3):1-23

Condie SA, Dunn JR (2006) Seasonal characteristics of the surface mixed layer in the Australasian region: implications for primary production regimes and biogeography. Mar Freshw Res 57: 569-590

De'ath G (2002) Multivariate regression trees: a new technique for constrained classification analysis. Ecology 83(4):1103-1117

De'ath G (2007) Boosted trees for ecological modeling and prediction. Ecology 88(1):243-251

DeVantier LM, De'ath G, Turak E, Done TJ, Fabricius KE (2006) Species richness and community structure of reefbuilding corals on the nearshore Great Barrier Reef. Coral Reefs 25(3):329-340

Drew EA (2001) Ocean nutrients to sediment banks via tidal jets and Halimeda meadows. In: Wolanski E (ed) Oceanographic processes of coral reefs: physical and biological links in the Great Barrier Reef. CRC Press, Boca Raton, FL, p 255-267

Dufrêne M, Legendre P (1997) Species assemblages and indicator species: the need for a flexible asymmetrical approach. Ecol Monogr 67(3):345-366

Ellis DM, DeMartini EE (1995) Evaluation of a video camera technique for indexing the abundances of juvenile pink snapper, Pristipomoides filamentosus, and other Hawaiian insular shelf fishes. Fish Bull 93(1):67-77

Fabricius K, De'ath G (2001) Biodiversity on the Great Barrier Reef: large-scale patterns and turbidity-related local loss of soft coral taxa. In: Wolanski E (ed) Oceanographic processes of coral reefs: physical and biological links in the Great Barrier Reef. CRC Press, Boca Raton, FL, p $127-144$

Fager EW, Longhurst AR (1968) Recurrent group analysis of species assemblages of demersal fish in the Gulf of Guinea. J Fish Res Board Can 25(7):1405-1421

Friedman JH (2001) Greedy function approximation: a gradient boosting machine. Ann Stat 29(5):1189-1232

Gray JS (2001) Marine diversity: the paradigms in patterns of species richness examined. Sci Mar 65(Suppl 2):41-56

Hancock GJ, Webster IT, Stieglitz TC (2006) Horizontal mixing of Great Barrier Reef waters: offshore diffusivity determined from radium isotope distribution. J Geophys Res 111:C12019, doi:10.1029/2006JC003608

Larcombe P, Carter RM (2004) Cyclone pumping, sediment partitioning and the development of the Great Barrier Reef shelf system: a review. Quatern Sci Rev 23:107-135

Laurans M, Gascuel D, Chassot E, Thiam D (2004) Changes in the trophic structure of fish demersal communities in West Africa in the three last decades. Aquat Living Resour 17: 163-173

Leathwick JR, Elith J, Francis MP, Hastie T, Taylor P (2006) Variation in demersal fish species richness in the oceans surrounding New Zealand: an analysis using boosted regression trees. Mar Ecol Prog Ser 321:267-281

Letourneur Y, Kulbicki M, Labrosse P (1998) Spatial structure of commercial reef fish communities along a terrestrial 
runoff gradient in the northern lagoon of New Caledonia. Environ Biol Fish 51:141-159

Longhurst AR, Pauly D (1987) Ecology of tropical oceans. Academic Press, San Diego, CA

Lowe-McConnell RH (1987) Ecological studies in tropical fish communities. Cambridge University Press, Cambridge, p 213-223

Magurran AE, Henderson PA (2003) Explaining the excess of rare species in natural species abundance distributions. Nature 422(6933):714-716

McManus JW (1997) Tropical marine fisheries and the future of coral reefs: a brief review with emphasis on Southeast Asia. Coral Reefs 16:121-127

Newman SJ, Williams DM, Russ GR (1997) Patterns of zonation of assemblages of the Lutjanidae, Lethrinidae and Serranidae (Epinephelinae) within and among mid shelf and outer shelf reefs in the central Great Barrier Reef. Mar Freshw Res 48:119-128

Pitcher CR, Poiner IR, Hill BJ, Burridge CY (2000) Implications of the effects of trawling on sessile megazoobenthos on a tropical shelf in northeastern Australia. ICES J Mar Sci 57(5):1359-1368

Pitcher CR, Venables W, Ellis N, McLeod I and others (2002) GBR Seabed Biodiversity Mapping Project: Phase 1. CSIRO/AIMS/QDPI Report to CRC-Reef. Available at: http://www.reef.crc.org.au/resprogram/ programC/seabed/Seabedphase1rpt.htm

Porter-Smith R, Harris PT, Andersen OB, Coleman R, Greenslade D, Jenkins CJ (2004) Classification of the Australian continental shelf based on predicted sediment threshold exceedance from tidal currents and swell waves. Mar Geol 211:1-20

R Development Core Team (2005) R: a language and environment for statistical computing. R Foundation for Statistical Computing, Vienna

Ramm DC, Pender PJ, Willing RS, Buckworth RC (1990)

Editorial responsibility: Howard Browman (Associate Editorin-Chief), Storebø, Norway
Large-scale spatial patterns of abundance within the assemblage of fish caught by prawn trawlers in northern Australian waters. Aust J Mar Freshw Res 41:79-95

Sainsbury KJ, Campbell RA, Lindholm R, Whitelaw AW (1997) Experimental management of an Australian multispecies fishery: examining the possibility of trawl induced habitat modification. In: Pikitch EK, Huppert DD, Sissenwine MP (eds) Global trends: fisheries management. American Fisheries Society, Bethesda, MD, p 107-112

Spalding M, Grenfell A (1997) New estimates of global and regional coral reef areas. Coral Reefs 16:225-230

Stobutzki IC, Miller MJ, Jones P, Salini JP (2001) Bycatch diversity and variation in a tropical Australian penaeid fishery: the implications for monitoring. Fish Res 53(3):283-301

Thompson GG, Withers PC (2003) Effect of species richness and relative abundance on the shape of the species accumulation curve. Austral Ecol 28:355-360

Watson RA, Dredge MLC, Mayer DG (1990) Spatial and seasonal variation in demersal trawl fauna associated with a prawn fishery on the central Great Barrier Reef, Australia. Aust J Mar Freshw Res 41:65-77

Wilkinson CR, Cheshire AC (1988) Cross shelf variations in coral reef structure and function-influences of land and ocean. In: Choat JH, Barnes D (eds) Proc 6th Int Coral Reef Symp, Vol. 3. Symposium Executive Committee, Townsville, p 227-233

Williams DM (1991) Patterns and processes in the distribution of coral reef fishes. In: Sale PF (ed) The ecology of fishes on coral reefs. Academic Press San Diego, CA, p 437-474

Willis TJ, Millar RB, Babcock RC (2000) Detection of spatial variability in relative density of fishes: comparison of visual census, angling and baited underwater video. Mar Ecol Prog Ser 198:249-260

Wolanski E (1994) Physical oceanographic processes of the Great Barrier Reef. Marine Science Series, CRC Press, Boca Raton, FL

Submitted: December 14, 2006; Accepted: July 27, 2007

Proofs received from author(s): November 17, 2007 